\title{
Editorial
}

\section{Biodiversity and climate change in the Neotropical region.}

The isolation of South America from Central America and Africa during the Tertiary Period left a strong imprint on the biota of the Neotropics. For almost 100 million years Neotropical flora, fauna and microorganisms evolved in completely isolation. The emergence of a continuous land bridge, 3 Ma years ago, between Central and South America is well documented and is demonstrated by the arrival of temperate elements in South American highlands and concurrent appearance of South American taxa in Central America. There is strong evidence of displacement of the Neotropical fauna, especially mammals, by northern immigrants, but the same is not observed in relation to plants. The mix of taxa in extant Mexican tropical floras derived from tropical South America, tropical Central America, and from remnants of northern tropical Eocene floras is strong evidence for the impact that the land bridge through the Panamanian isthmus had on the Neotropical region (Burnham \& Graham, 1999).

Data on temperature changes during the late Tertiary and Quaternary Periods point to low-latitude temperature fluctuations of up to $6{ }^{\circ} \mathrm{C}$. Proposals of accompanying widespread rainfall fluctuations are less equivocal. Rainfall probably varied regionally, resulting in a mosaic of habitats controlled by river migration, sea level fluctuations, local dryness, and local uplift. Zones postulated as refugia provide testable hypotheses using neo-ecological and paleo-ecological data (Burnham \& Graham 1999). Although the refugia hypothesis is questioned today (Bush \& Oliveira 2006), undoubtedly the effects of climate change on vegetation physiognomy played a crucial role in shaping not only the present pattern of mammalian distribution (de Vivo \& Carmignotto 2004), but also of present biomes and ecotones.

The final result of this long process of genesis and evolution of the Neotropical region, is that most of the Neotropical countries, such as Brazil, Colombia, Ecuador and Peru, are on the higher positions of any ranking of species richness. Brazil, in particular, occupies the first position in such rankings and is therefore considered the most Megadiverse country. So during millions of years there was a synergism between gradual and slow climate changes and speciation, giving time for natural selection and other evolutionary tolls to play their role.

Sometime between 50.000 and 20.000 years ago, man arrived in the Neotropical region, and started to change this scenario, hunting some species to extinction, burning some areas and promoting local changes in rivers and estuaries. But it was in 1.500 with the arrival of the European that land transformation processes really sped up, and the time scale of environmental changes jumped from thousands to hundreds of years. Five hundred years later we are experiencing yet another jump in time scale, as climate and other environmental changes are now measurable in decades. There is a growing discrepancy between the speed of the evolutionary process and that of climate changes. As a consequence there is an exponential increase in extinction rates (Thomas et al. 2004) in particular in the Neotropical region.

There is an urgent need to input authoritative knowledge on the likely impacts of climate change on biodiversity. There is a reasonable scientific consensus about the expected types of impacts on species and ecosystems, and a growing catalogue of documented changes that are consistent with climate change predictions. Nevertheless, there is much uncertainty about how individual species and ecosystems will respond to the combined impacts of future climate change and other pressures on biodiversity.

Siqueira \& Peterson (2003) working with 162 tree species of the Brazilian Cerrado, have shown that, in an optimistic scenario of up to $2{ }^{\circ} \mathrm{C}$ increase in average temperature, 18 species tend to disappear, in a more realistic scenario of up to $4{ }^{\circ} \mathrm{C}$ increase in average temperature, this number jumps to 56 species that probably will become extinct. Colombo \& Joly (in press) used the same model to study 38 Atlantic Forest species of trees, and have shown that, in a scenario of up to $4{ }^{\circ} \mathrm{C}$ increase in average temperature, the area today occupied by these species is reduced in $65 \%$.

In Brazil, climate change is even more strongly linked with biodiversity loss, since 75\% of the country's emission of green house effect gases/GEG comes from burning forest to use the land for cattle and/or soybeans plantations. Therefore, in my opinion, Brazil has an historical opportunity and a moral obligation to start the Post-Kyoto Negotiations establishing a self-imposed, reduction target of, at least 35\%, on its emissions of green house gases, achieved through reducing deforestation rates in $50 \%$. A country with an energy source matrix where more the $90 \%$ of the energy used comes from hydroelectric power stations and 
where at least $30 \%$ of the cars are running with sugar cane alcohol (without considering that all gasoline sold in Brazil has, at least, $20 \%$ of sugar cane alcohol), makes Brazil the unique case were a reduction in GEG can be made without jeopardizing the economic development of the country. The reduction in the deforestation rate, to achieve the self imposed reduction in GEG emission, must be measurable, permanent and monitored by Brazilian and International Research Institute/Organizations.

If Brazil stops incinerating its rich biodiversity (in large part yet unknown by science),, giving the future generations a chance to use this natural asset in a more sustainable way, the country will voluntarily reduce its rate of GEG emissions. Obviously this will have a cost, and in my opinion it should be paid by developed countries, if the countries reduction in deforestation rates complies with the target set.

\section{References}

BURNHAM, R.J. \& GRAHAM, A. The history of Neotropical vegetation: new developments and status. Ann. Missouri Bot. Gard., v.86, n.2, p. 546-589, 1999.

BUSH, M.B. \& OLIVEIRA, P. E. The rise and fall of the Refugial Hypothesis of Amazonian speciation: a paleoecological perspective. Biota Neotrop. 6(1): available at http://www.biotaneotropica.org.br/v6n1/en/abstract?point-of-view+bn00106012006

COLOMBO, A.F. \& JOLY, C.A. 2008. Potential consequences of global climate change for arboreal species of the Atlantic Forest of Brazil. Conserv. Biol. (submitted).

VIVO, M. \& CARMIGNOTTO, A.P. 2004. Holocene vegetation change and the mammal faunas of South America and Africa. J. Biogeogr. 31:943-957.

SIQUEIRA, M.F. \& PETERSON, A.T. Consequences of global climate change for geographic distributions of Cerrado tree species. Biota Neotrop. 3(2): available at http://www.biotaneotropica.org.br/v3n2/pt/abstract?article+BN00803022003.

THOMAS, C.D., CAMERON, A., GREEN, R.E., BAKLENES, M., BEAUMONT, L.J., COLLINGHAM, Y.C., ERASMUS, B.F.N., SIQUEIRA, M.F., GRAIGNER, A., HANNAH, L., HUGHES, L., HUNTLEY, B., van JAARSVELD, A.S., MIDGLEY, G.F. MILES, L., ORTEGA-HUERTA, M.A., PETERSON, A.T., PHILLIPS, O.L. \& WILLIAMS, S.E. 2004. Extinction risk from climate change. Nature 427:145-148.

\section{Carlos Alfredo Joly}

Department of Botany, Biology Institute, State University of Campinas, CP 6109, CEP 13083-970, Campinas/SP, Brazil and Member of the Stirring Committee of the BIOTA/FAPESP Program 